\title{
ANAEMIA AND HOOKWORM IN GURKHA RECRUITS
}

\author{
Captain B. D. BONAR, M.B., B.Ch., B.A.O., R.A.M.C. * \\ Training Depot The Brigade of Gurkhas, Sungei Patani \\ Flight-Lieutenant I. D. HOPKIN, B.Sc., M.B., Ch.B., R.A.F. $\dagger$ \\ 4 R.A.A.F. Hospital, Butterworth
}

\section{Introduction}

IN October 1970 three hundred and twenty-nine Gurkha recruits arrived at the Training Depot The Brigade of Gurkhas in Malaysia to undergo basic training. They had been selected from ten times that number in Nepal on the basis of intelligence and physique. They had all had an initial Pulheems examination.

Nepal is a developing country and the standard of nutrition is therefore below that of the developed world. It was thought that it would be interesting to measure the haemoglobin $(\mathrm{Hb})$ of these young men who were the cream of Nepalese youth. At the same time their faeces were examined for hookworm and a clinical trial was carried out on the effect of Bephenium Hydroxynaphthoate (Alcopar) in the treatment of infestation with hookworm.

\section{Method}

Each recruit as part of his pre-service Pulheems examination had blood taken for $\mathrm{Hb}$ examination and was issued with a plastic box for a specimen of faeces. There were two companies of recruits and the medical orderly of each was responsible for the collection of specimens from that company.

The $\mathrm{Hb}$ was measured by the Cyanmethaemoglobin method and expressed both in grammes per cent and as a percentage of normal (Haldane). The faeces were examined for ova and cysts by the Pathological Department of 4 Royal Australian Air Force Hospital, Butterworth.

All recruits whose $\mathrm{Hb}$ was found to be 80 per cent or less were treated with Ferrous Gluconate $(35 \mathrm{mg} \mathrm{Fe}$ ) three times daily. At the beginning of training all recruits in No. 1 Training Company received $5 \mathrm{~g}$ of Alcopar while fasting on two successive mornings under the direct supervision of platoon N.C.O's who had been briefed by the Regimental Medical Officer.

Number 2 Training Company did not receive any such treatment. At the end of training-six months later, $\mathrm{Hb}$ and faeces were again checked.

\section{Results}

a. On arrival the average $\mathrm{Hb}$ was 87 per cent. There were thirty-seven recruits, eleven per cent of the total, in whom the $\mathrm{Hb}$ was 80 per cent or below. The mean $\mathrm{Hb}$ in the latter group was 73 per cent. One recruit had a $\mathrm{Hb}$ of 46 per cent and was admitted to hospital for treatment. One who had a $\mathrm{Hb}$ of 56 per cent was found on examination to have pulmonary tuberculosis.

\footnotetext{
* Now Military Maternity Hospital, Woolwich. $\dagger$ Now c/o I.P.T.M., Royal Air Force, Halton.
} 
b. Ankylostoma duodenale was present in three hundred and six recruits initially. This comprised ninety per cent of the total.

At the end of training the mean $\mathrm{Hb}$ was 96 per cent, an overall increase of 9 per cent. The mean $\mathrm{Hb}$ of those whose $\mathrm{Hb}$ was 80 per cent or less originally was 92 per cent, an increase of 19 per cent. There were still three recruits whose $\mathrm{Hb}$ was 80 per cent or below at the end of training.

There was no significant difference between Nos 1 and 2 Companies in the numbers infested with Ankylostoma duodenale at the end of training.

Number 1 Company had one hundred and sixteen out of one hundred and fortynine still infested. Number 2 Company had one hundred and nineteen out of one hundred and forty-eight still infested. This represents about an eighty per cent infestation in each.

\section{Conclusion}

A surprisingly high number of apparently fit young Gurkha recruits were found to be anaemic and infested with hookworm on arrival at the Training Depot.

$\mathrm{The} \mathrm{Hb}$ level increased dramatically over the six-month training period, presumably due to the improved nutrition. The group who were treated with the iron compound showed a particularly marked increase in $\mathrm{Hb}$. However, an ideal of 100 per cent $\mathrm{Hb}$ concentration had not been reached and one wonders whether the diet of recruits is entirely adequate. Alcopar administration in No. 1 Company made no difference in the level of hookworm infestation when compared with a second of equal strength. It is advised that a routine $\mathrm{Hb}$ estimation be part of the initial or pre-service Pulheems examination in order to detect anaemenia. There is no evidence to suggest that routine dosing of recruits with Alcopar will decrease the level of hookworm infestation. 